\title{
TOURISM AND EXTENSION IN HIGHER EDUCATION: The UFS de Braços Abertos project and demystifying percpetions of the university
}

\author{
Pedro Henrique Jesus Santos ${ }^{a}$ \\ Rosana Eduardo da Silva Leal ${ }^{b}$
}

\begin{abstract}
University extension is an inseparable tool from teaching and research, and aims to popularize science by providing services to society. In higher education in Tourism, extension activities are indispensable in the process of raising citizenship awareness among professionals in the area. Based on these premises, this article reflects on the importance of university extension as a tool for higher education in Tourism, as well as for democratizing access to university, taking as its field of study the project UFS de Braços Abertos. We begin with a report of experience of one of the actions of the project, in partnership with the Física Show, conducted with elementary and high school students from the city of Propriá, in the state of Sergipe/SE. The aims were: i) to critically discuss the common sense vision of the University as a restricted, excluding space that is distant from society, ii) to analyze the importance of the projects UFS de Braços Abertos and Física Show in the career choice of students in Basic Education and iii) to reflect on the importance of university extension projects for academic and professional training on the course in Tourism at Universidade Federal de Sergipe (UFS). As theoretical and methodological contributions, we adopted participant research (GIL, 2008), linked to descriptive research, and a qualitative approach. Our reflections indicate an increasing need to discuss university extension activities, bearing in mind that they provide a practical laboratory where theory and practice can be combined, contributing to students' academic and professional training. Extension projects also provide opportunities for inclusion of the community outside the walls of UFS. We conclude that since tourism is an activity that encompasses other areas of knowledge, which are necessary for its performance, studies in this area should also include transdisciplinary extension activities inherent to the learning process.
\end{abstract}

\section{Keywords:}

Tourism

Higher Education

Extension

UFS 


\section{INTRODUCTION}

Brazilian public higher education institutions have always provided significant results for society by solving problems in various spheres, through their teaching, research and extension activities, in a triad centered on policies and strategies aimed at quality and improvement of teaching, as well as the production of scientific research and university extension activities, so that they can continue to respond to social demands and give back some contribution to society.

Within this perspective, university extension is an inseparable tool from teaching and research, and is aimed at popularizing science through the provision of services to society, through workshops, lectures, products and projects aimed at promoting inclusion of the community in the University. In this context, the creation of pedagogical scripts, linked to the UFS de Braços Abertos extension project in partnership with Física Show, both at the Federal University of Sergipe, aims to welcome students in Basic Education into the University, providing tools that contribute to democratizing access to the public university space, and consequently, promoting and strengthening knowledge about academic life.

The UFS de Braços Abertos project is run by a team of ten students on the Tourism course at the Federal University of Sergipe (UFS/DTUR). Based on the knowledge absorbed during the course, the project aims to enable the implementation of educational and inclusive practices on the campus of this University, through the planning, organization and execution of visiting itineraries.

The project began in 2013 and since then, it has presented the courses and departments of the university, including its laboratories, and research and extension projects to students in the eighth and ninth grades of elementary school, and in the first, second and third grades of high school, in the State of Sergipe. It has also invited and included schools in the city of São Cristóvão, where the University is located, since a significant portion of public and private schools in the city do not have much knowledge about the UFS and its activities, or have not had the opportunity to visit it.

The Física Show is run by a team of eleven students from the São Cristóvão campus, and is linked to the Physics Department of the Federal University of Sergipe (UFS/DFI). The project takes place on the Itabaiana and São Cristóvão campuses, and aims to popularize science, through activities involving scientific practices, to awaken the curiosity and promote understanding and knowledge among the general public and students in Basic Education.

In this context, this study reflects on the importance of university extension as a tool for higher education in Tourism and for democratizing access to the university, taking as its field of study the UFS de Braços Abertos project. It also aims to: i) critically discuss the common sense vision of the University, as a restricted, excluding space that is distant from society, ii) analyze the importance of the UFS de Braços Abertos and Física Show projects in the career choice of school students in Basic Education and iii) reflect on the importance of university extension projects for academic and professional training of students in the UFS Tourism course.

In regard to the relations and individual actions that characterize the researched phenomenon, the research methodology was developed by means of participant research linked to the descriptive research. A qualitative approach was used, as well as a bibliographical review of the texts that guide the discussions, and photographic records of the visit.

In the results, we reflect on the importance of university extension for higher education courses in Tourism, and demystify some issues that cause the University to be perceived as a distant and unreachable space. We emphasize the role of the UFS de Braços Abertos extension projects in partnership with Física Show in this process, and student's career choice. The next section demonstrates the importance of research based on the UFS de Braços Abertos and Física Show university extension projects.

\section{Problem and Relevance}

There is a pressing need to bring society closer to the spaces of the University, and to scientific production, i.e., research and extension. Higher education should not be restricted to be the university campus, bearing in mind that it is linked to the demands of the community and should be an inseparable part of this exterior space of production of knowledge, and that communities are also producers of popular knowledge and activities that are often the objects of scientific research. During the visits, the school students expressed perplexity and uncertainty, faced with the unknown environment, which often seems far removed from anything they have seen in their daily lives. It is well known that entry to higher education is filled with uncertainties, but the proposal of the UFS de Braços Abertos Project is, essentially, to present the various interfaces and opportunities for entering the University, by presenting the courses and departmental structures, in partnership with the departments. Through these visits, it is hoped that the school students will take a particular interest in one or other course, as they learn about the curricula, scientific research projects, and university extension activities of each course. 


\section{METHODOLOGY}

For the theoretical and methodological contribution, we used Gil (2008, p. 50), who defines participant research as "[...] the involvement of researchers and the respondents in the research process. In this sense, they distance themselves from the principles of academic scientific research. The objectivity of classical empirical research is not observed". Our direct participation in the process of designing this research allows us to understand the subjectivity of the facts that influence students' perceptions of the University, considering the relations between them and the university environment.

The adoption of this participatory research focused on the report of experience that took place through our involvement in presenting the Tourism course to the visiting students. Through these presentations, questions about the impacts of the UFS de Braços Abertos and Física Show extension projects prompted further reflections about the subject. Similarly, the discussion of scientific articles that took place during the Cycle of Studies linked to the UFS de Braços Abertos project, led by the coordinating professor of the project, provided the basis for the theoretical framework adopted for this research. Secondary data were collected through CAPES, OASIS and Google Academic platforms. According to Marconi and Lakatos (2003, p. 183):

Bibliographic research, or from secondary sources, covers all bibliography already made public in relation to the subject of study, from single publications, bulletins, newspapers, periodicals, books, research, monographs, theses, cartographic material, etc., to oral media: radio, tape and audiovisual recordings: films and television. Its purpose is to place the researcher in direct contact with everything that has been written, said or filmed about a certain subject, including conferences followed by debates that have been transcribed in some way, either published or recorded.

This research is qualitative and descriptive, as it aims to contextualize the development of the visits to UFS, considering the specificities of the university extension projects, as well as the activities performed by them. We also made photographic records of the students who participated in the visit to the University, at moments of interaction during the presentations held on campus for the UFS de Braços Abertos and the Física Show projects, in order to reaffirm what had taken place.

\section{RESULTS}

It is important to discuss, from the outset, the fact that university extension activities also provide a practical "laboratory" for the students of the Tourism course at UFS, since the knowledge obtained during the classes can be applied and correlated to various audiences and contexts. The practical knowledge gained is indispensable for the process of professional training, shaping the transdisciplinarity of Tourism (FARIAS; SONAGLIO, 2013). Thus, the experiences gained through the elaboration of pedagogical scripts, presentations, and planning, among other activities linked to the UFS de Braços Abertos Project, gave the graduates valuable experience for their university studies, and later on, for the job market. This research is a report of an experience with a group of 72 students from the Bradesco Foundation, in the city of Propriá/SE, that took place on the morning of August 8, 2019, from 8am to $12 \mathrm{pm}$.

The visit to the São Cristóvão Campus of the Federal University of Sergipe took place through an itinerary conducted in partnership with the Physics, Mathematics and Law courses. In this research, we focus, specifically, on the extension projects Física Show, presented by the Physics course, and UFS de Braços Abertos. The proposal of the Física Show project is to present physical phenomena in a didactic and creative way, to students in Basic Education, seeking to stimulate their curiosity and understanding of scientific phenomena, and give them scientific experiences. Thus, the phenomenon studied was identified based on the experience and participation with the group of students.

The visits to the University are based on itineraries, which are planned in advance by the ten monitors of the UFS de Braços Abertos project during the weekly planning meetings, and in response to requests from the courses to be visited by the schools. The courses are booked in person, through social networks or official communication sites. In the visit that is the particular focus of this study, the courses in Law, Degree in Mathematics, Physics and Tourism were presented. It is important to emphasize that the planned itineraries include a maximum number of three courses, with one hour of presentation time for each (the fact that there were four courses in this visit was an exception). The presentations are adapted to the profile of each school, and are offered without any cost for the students, the schools, or the course departments involved.

Initially, visiting students from the Bradesco Foundation were welcomed in the Central Library of UFS, the location previously planned to receive the visitors. They were then led to the auditorium, with some other university buildings being pointed out along the way, where the presentations of courses in Tourism, Law and Mathematics took place, in the Center for Education and Human Sciences. As the visitors 
arrived at the auditorium, the speakers presented the curricular structure of the course, the academic center, the number of professors, and the research and extension projects, keeping to a maximum presentation time of one hour. Afterwards, the Física Show Project was presented, in a suitable auditorium for the use technological sound and image resources that enabled execution of dynamics based on scientific phenomena, using equipment that allowed for the interaction of the team of monitors, who presented the project to the students in an interactive, entertaining way, including the community in the process of doing science ( Attachment Photo I).

The university extension projects are designed to include the external community and reflect on the common sense vision of the University as space that is restricted, exclusive, and distant from society, especially in the perception of students in Basic Education. This reality is also observed in the perception of students who visit the Federal University of Sergipe (UFS), through the UFS de Braços Abertos Project, as it is clearly seen that the students feel their own reality is far removed from the university universe. This is due to a lack of knowledge of projects aimed at receiving students in Basic Education and demystifying these discourses and the vision around university life.

After the presentations, the visit was completed at the Praça da Democracia, a symbol of democratization of knowledge and a space of the University that symbolically represents the UFS de Braços Abertos Project, as a tool for transforming the lives of students in Basic Education, popularizing knowledge and promoting the exchange of experiences (Annex - Photo II).

University extension has long been understood as an inseparable field from teaching and research, also being a dimension of academic productions (CF/1988). However, university extension acts as a tool to provide specialized services to the community and promote academic productions, demonstrating its importance within the function of the Brazilian public university (LDBEN/1996). At UFS, extension is approved by Resolution 47/2019/CONEPE, integrating teaching and research to induce interactions and transformations between higher education and society.

It is crucial to take into consideration the recent pressures and demands on the public University, so that it can meet the various social demands, including strengthening ties with Basic Education, although since the Middle Ages, the public University has been developing its social function with students at this level of education. Later, in modern times, it was assigned the function of research and, more recently, responsibility through university extension (OLIVEIRA; MELO, 2013). In discussions about the role of universities, it is urgent and necessary to highlight the role of extension projects such as the UFS de Braços Abertos and Física
Show, due to their potential to present students from the Sergipe countryside and schools around the UFS with other possible career choices, because sometimes, students are unable to see beyond the reality of their day-to-day lives, due to the interior and suburban contexts in which they live.

Therefore, for students living in complex contexts, attending high school is often, in itself, an achievement not attained by other family members and friends. However, these disparities are exacerbated by the absence of any follow up focused on the university entrance exam, and the student's misguided concepts of higher education (GNECCO JÚNIOR; RAMOS, 2010). These social barriers make it difficult for students from Brazilian public schools to access and enter University. University extension projects such as the UFS de Braços Abertos and the Física Show have a role of popularizing the scientific knowledge produced in the university, through educational and didactic actions, answering questions about the choice of career, through critical reflection (HALLAL; MULLER, 2017).

In the current context, where social disparities are being reinforced when it comes to access by minority classes to quality public universities, the tendency is for them to be impelled to access the academic context, and this is where university extension acts as a bridge, dialoguing with Basic Education and the external community and seeking to reduce or remove the barriers that prevent access to University, based on recent debates (OLIVEIRA; MELO, 2013) and in a more intense way on the inclusion and democratization of higher education.

Considering the barriers to accessing University, there are many social struggles around the world for the achievement and realization of rights, particularly for more schooling, as there are many factors imposed on the general population, which requires access to higher education (OLIVEIRA; MELO, 2013). The university extension projects investigated here are not intended to guarantee access to any particular higher education course, but rather, to give students in Basic Education contact with the university context in different areas, such as courses, academic production, departmental structures and even the public areas, cultural events and areas of natural beauty within the University.

It is also pertinent and necessary to emphasize that the UFS de Braços Abertos extension project helps to deconstruct the perception, among students in Basic Education, that the University is an environment solely for gifted people, and therefore, a utopian place. But during the course presentations, a shift in these perceptions is seen among the students, with some of the students identifying with a certain area of knowledge. 


\section{PrACTICAL IMPLICATIONS AND CONCLUSIONS}

Based on this report of experience, we were able to identify that university extension projects play a fundamental role in the process of identification (or not) of young people from rural towns of Sergipe with the University, so that besides choosing a course, these young people are placed in a position of protagonists in that choice, exercising their social function as criticalreflective subjects.

This research also highlights the importance of extension projects for their contributions to society and their capacity to present students with career possibilities and different realities that go beyond what they see in their daily lives. Therefore, creating research, teaching and extension projects that include the community in the academic context, on a continuous basis, is very important for ensuring that scientific research is not restricted to within the four walls of the university, i.e. research that studies phenomena within the communities without giving back anything in return.

Tourism, as an activity that encompasses other areas of knowledge, necessary to its performance, also needs to carry out extension activities, in partnership with other areas of knowledge, to promote the transdisciplinary actions inherent to the learning process. Thus, UFS de Braços Abertos is projected not only within the University itself, but also to public schools in the State of Sergipe, through itineraries of visits to the University, promoting innovation through actions involving tourism and teaching, as an area that is rarely addressed by the tourism industry of Sergipe.

It is essential that university extension actions in Tourism act in a transdisciplinary way in the process of knowledge construction, especially for students in Basic Education, bringing in methods and categories from other areas that can contribute to scientific research and extension activities in Tourism, and not only maintaining links with other areas of knowledge for purely commercial purposes.

The effectiveness of the UFS de Braços Abertos Project, as demonstrated here, is not restricted to the number of actions completed over its seven years in operation, but extends to the possibilities of attracting and stimulating the interest of students from complex contexts in entering public higher education, in this case at the Federal University of Sergipe. The results of the project are seen in the number of these students who later enroll in courses at the University, as a direct reflection of the process of deconstructing shared socio-historical perceptions of the University as some kind of utopian place that is far removed from their daily lives.

\section{REFERENCES}

BRASIL. Da Ciência, tecnologia e Inovação. Brasília: 1998. Available at: <http://www.planalto.gov.br/ccivil 03/ constituicao/constituicao.htm. Accessed on: June 26, 2020.

BRASIL. Estabelece a Lei de Diretrizes e Bases da Educação. Brasília: 1996. Available at: http:// www.planalto.gov.br/ccivil_03/leis/19394.htm. Accessed on: June 26, 2020

FARIAS, M. F.; SONAGLIO, K. E. Perspectivas Multi, Pluri, inter e Transdisciplinar no Turismo. Revista Iberoamericana de Turismo. V. 3. N. 1, p. 71-85, 2013.

GIL, A. C. Métodos e técnicas de pesquisa social. 6. ed. São Paulo: Atlas, 2008

GNECCO JÚNIOR, L.: RAMOS, V. L.: O Marketing a Serviço da Educação - Projeto Conhecendo a UFSC: uma volta pelo campus sem sair de sala de aula. In: X Colóquio Internacional de Géstion Universitaria en América de Sur: balance y prospectiva de la Educación Superior en el marco de los Bicentenarios de América del Sur. Mar del Plata: 8, 9, 10, Dec., 2010.

HALLAL, D. R.: MULLER, D. Turismo e Educação Patrimonial: a experiência das visitas guiadas pelos prédios da UFPEL. Expressa extensão. V. 22, n. 2, p. 113-128, Jul. Dec. 2017.

MARCONI, M. A.; LAKATOS, E. M. Fundamentos de Metodologia Científica. 5. ed. São Paulo: Atlas, 2003.

OLIVEIRA, N. F. C.; MELO, S. D. G.; In: 26ª Reunião Nacional da ANPEd. Goiânia-GO, Dec. 29 - Oct. 2, 2013. 